\title{
HYDROBIA ULVAE: A DEPOSIT-FEEDER FOR CLEANING LIVING HARD-SHELLED FORAMINIFERA
}

\author{
L. Rossignol ${ }^{1}$, C. DupuY ${ }^{1, *}$, PY. Pascal ${ }^{1}$ And J. -P. Debenay ${ }^{2}$
}

\section{ABSTRACT}

This study proposes a new method for fast and inexpensive extraction of a large number of living foraminifera for laboratory cultures. The method is a significant improvement over current extraction methods, which are highly timeconsuming. Several treatments were designed to test the method. Sediment bearing foraminifera from Brouage Mudflat (Atlantic coast of France) was washed through a 50- $\mu \mathrm{m}$ sieve and distributed in glass Petri dishes with 20, 40 and 80 specimens of Hydrobia ulvae, a common gastropod from European intertidal mudflats. As a control experiment, one dish was treated similarly but maintained without Hydrobia. After two days, most of the sediment in the Hydrobia treatments was compacted into small cylindrical gastropod feces, and the tests of living benthic foraminifera (Ammonia tepida and Haynesina germanica) were clean and easily visible. Additional experiments showed that the foraminifera were not ingested by Hydrobia ulvae, and could be picked quickly and easily.

\section{INTRODUCTION}

Laboratory studies using living foraminifera for biological and ecological investigation have been used for more than a half-century and provide important, complementary data to field-base studies (e.g., Myers, 1935; Le Calvez, 1938; Jepps, 1942; Arnold, 1954). They have been increasingly used for ecological and environmental studies (e.g., Bradshaw, 1961; Bender and Hemleben, 1988; Bijma and others, 1990; Stouff and others, 1999; Khare and Nigam, 2000; Heinz and others, 2002). These studies require separation of live individuals from the sediment without harming them and efficient techniques to differentiate live and dead individuals. Live and dead individuals can be distinguished using vital staining, such as fluorescent probes combined with direct observation of cytoplasm and the reticulopodial network (Murray and Bowser, 2000; Bernhard, 2000). However, before using these methods, it is first necessary to isolate individuals from the sediment. In samples containing a high proportion of mud, the tests are hard to discern, even more so because they are often hidden in small-particle agglutinated cysts, making observation quite difficult. The sediment must be sieved to concentrate the foraminifera before observation (e.g., Bowser and others, 1992; Linke and others, 1995; Moodley and others, 2000), but even after sieving, the tests are still scattered among the coarser sediment particles and incased in their cysts. The foraminifera may be separated from the sediment by using their negative geotaxis, which makes them crawl

${ }^{1}$ CRELA, UMR 6217, Université de La Rochelle, Pôle Sciences, AV. Michel Crépeau, 17042 La Rochelle Cedex, France

2 Département de Géologie, Université d'Angers, UPRES EA 2644, 2 Bd Lavoisier, 49045 Angers Cedex, France

*E-mail: cdupuy@univ-lr.fr up the walls of their dishes or microscope slides put in the dishes (Arnold, 1974; Anderson and others, 1991; Bernhard, 2000). However, not all foraminiferal species exhibit such behavior (Bernhard, 2000), and infaunal species must be cleaned and picked out from the sediment with a brush or pipette. This is highly time consuming and may harm living individuals (Anderson and others, 1991; Carey, 1993).

This study proposes a new harmless biological technique for concentrating living hard-shelled foraminifera, such as Haynesina germanica and Ammonia tepida, from muddy sediment using the feeding behavior of a small depositfeeding gastropod, Hydrobia ulvae.

\section{MATERIAL AND METHODS}

The area selected for collecting foraminifera and Hydrobia ulvae was the upper part of the intertidal Brouage mudflat on the French Atlantic coast at latitude $45^{\circ} 54^{\prime} \mathrm{N}$ and longitude $1^{\circ} 7^{\prime} \mathrm{W}$ (Fig. 1). This area was selected owing to the high density of living foraminifera (110 individuals per $\mathrm{cm}^{3}$, Armynot du Chatelêt, communication, 2004) and because Hydrobia ulvae, a common gastropod from European intertidal mudflats, is the most abundant species among the macrofauna (Haubois and others, 2004). This snail is a deposit-feeder that inhabits muddy sand- and mudflats (Hayward and others, 1998). It ingests sediment and egests inorganic particles compacted into small cylinders (feces).

The sediment sample was collected at low tide by scraping off the first centimeter of sediment in an area where microphytobenthos was abundant (brown film on surface sediment). Seawater was collected in the same area. If the mud snails and foraminifera cannot be sampled at the same time, then it is necessary to maintain a ready stock of mud snails in the laboratory. This is quite easy since they can be kept living for several weeks if placed in sediment in a cold room $\left(5^{\circ} \mathrm{C}\right)$. In the laboratory, $1 \mathrm{~g}$ of sediment was sieved with seawater through a nylon mesh of $50-\mu \mathrm{m}$ openings to eliminate clay and fine silt-size particles. To eliminate additional fine grains, the remaining material was gently stirred in filtered $(0.2 \mu \mathrm{m})$ seawater and then allowed to stand for several seconds to let the foraminifera settle to the bottom. Supernatant seawater with fine suspended particles was then decanted, and seawater re-added. This operation was repeated until the supernatant water was clear. Finally, the processed sediment and foraminifera were distributed in a glass Petri dish $(16 \mathrm{~cm}$ diameter). Owing to the fragility of foraminiferal tests, it was impossible to stir the sediment strongly. Consequently, the tests remained incased in their fine-particle agglutinated cysts and flocs of fine sediments remained together with rare coarser grains. 


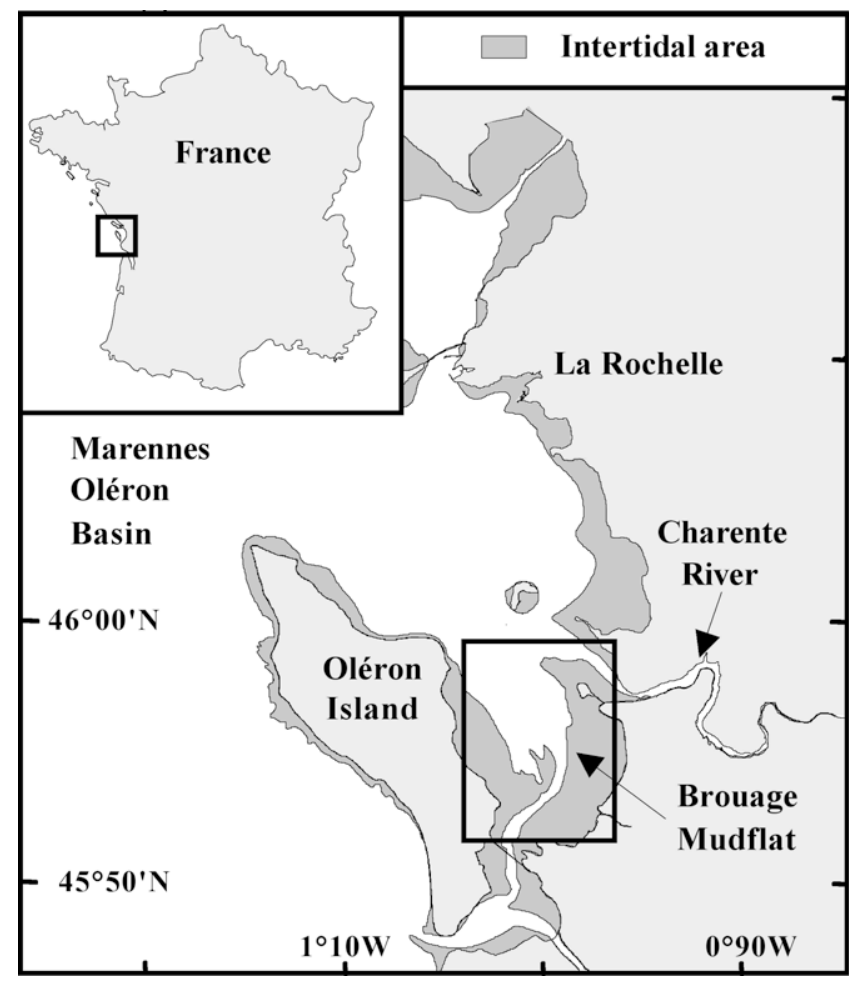

FiguRE 1. Location of the sampling site: Brouage mudflat. White: subtidal area, Gray: tidal area.

To test the efficiency of the treatment with Hydrobia, triplicate Petri dishes were prepared by additions of 40 and 80 specimens of Hydrobia ulvae, respectively. They were placed in a constant-temperature room $\left(18^{\circ} \mathrm{C}\right)$ and kept at a light/dark cycle of $12 \mathrm{~h} / 12 \mathrm{~h}$ for two days. The dishes were observed every day under a dissecting microscope. After two days, the number of hard-shelled foraminifera was counted in all dishes and the species were identified.

In addition, experiments were carried out to test whether or not the snails ingest foraminifera. Twenty Hydrobia were placed for 48 hours in triplicate Petri dishes, together with sediment collected in an area rich in living foraminifera and sieved as above. At the same time, six other Petri dishes were prepared with the same sediment but without gastropods. Three of these dishes without Hydrobia were used to count the number of foraminifera at the beginning of the experiment, and the three others were used as controls. At the end of the experiment 48 hours later, the number of foraminifera was counted in the six remaining dishes (three with Hydrobia and three controls without). Moreover, 50 Hydrobia were collected in an area rich in living foraminifera and sediment was collected at the same place in order to evaluate the density of living foraminifera. The shells of the Hydrobia collected in the field as well as those of the experiments (triplicate Petri dishes with 20 Hydrobia after $48 \mathrm{~h}$ ) were broken and their living material was extracted. Because the guts of Hydrobia are very small and difficult to open without potentially breaking foraminiferal tests (if present), we used a process previously devised by one of us (Debenay, communication, 2004.) for studying the gut contents of other gastropods. The living material of the gastropods was immersed for four days in
TABLE 1. Abundance of foraminifera (tests $\mathrm{g}^{-1} \mathrm{dw}$; $\mathrm{dw}=$ dry weight with standard deviation (SD) in the sediment after treatment with different densities of Hydrobia (Ulvae).

\begin{tabular}{lcc}
\hline \multicolumn{3}{c}{ Abundance $\left(\right.$ Tests $\left.^{-1} \mathrm{dw}\right) \pm \mathrm{SD}$} \\
\hline 40 H. ulvae & 80 H. ulvae \\
\hline Ammonia tepida & 121 & 129 \\
Haynesina germanica & 626 & 655 \\
Sum & 747 & 784
\end{tabular}

a sodium hypochlorite solution with available chlorine of $~$ $3 \%$ in order to remove organic material. Control experiments, which consisted of the immersion of foraminifera with cytoplasm (potentially living) in the same solution, had shown that the tests, even agglutinated ones, were very well preserved after four days in the solution (Debenay, communication, 2004).

To complete this experiment, six foraminifera were left with two H. ulvae for 24 hours in a Petri dish, and then observed to determine if they were still alive (based on pseudopodial activity).

\section{RESULTS}

\section{EFfect of Hydrobia ULVAE GraZing ON THE SEDIMENT}

During all the experiments with 40 and 80 gastropods, $H$. ulvae fed on the bottom of the dishes and on the food aggregates surrounding living foraminifera. This activity led to the sorting of the sediment and foraminiferal tests into three components: (1) feces of $H$. ulvae made up of small cylinders of compacted sediment; (2) clean foraminiferal tests; (3) a few remaining mineral sediment particles.

During the first day, feces production began, but the tests were still covered with a layer of fine sediment and/or food and were not easy to distinguish. After two days, snails had cleaned all the foraminiferal tests, which had become very easy to locate and pick (five seconds per specimen). It was easy to count them (Table 1). No improvement of the cleaning could be observed for experiments lasting more than two days. An additional benefit became evident. The foraminifera were unable to reconstruct their agglutinated cysts after cleaning because all the fine particles of sediment were aggregated. It appeared that the foraminifera had been cleaned but not ingested by the mud snail. In the dishes without $H$. ulvae, the tests kept their cysts of organic and mineral particles and could hardly be distinguished (Fig. 2). Furthermore, the compaction of the sediment into feces was more efficient with 80 gastropods than with 40 .

\section{EFFECT OF HYDROBIA ULVAE ON THE ForAMINIFERA}

The experiments were carried out with the same amount of sediment ( $1 \mathrm{~g})$ in all the Petri dishes. After two days, the number of foraminifera (12 \pm 2 Ammonia tepida and $4 \pm 2$ Haynesina germanica, proportions comparable to those found in the natural tidal flat at Brouage; Armynot du Chatelêt, communication, 2004) was not significantly different between treatments with or without 20 Hydrobia ulvae (Student $\mathrm{t}$ test: $\mathrm{p}<0.05$ ) and not significantly different from numbers at the start of the treatments 
A

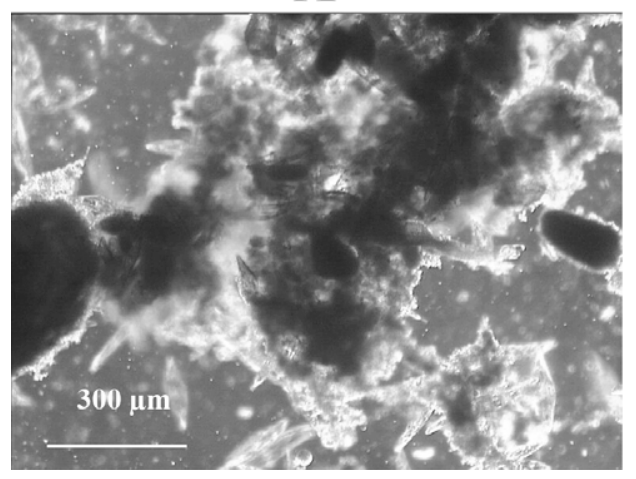

B

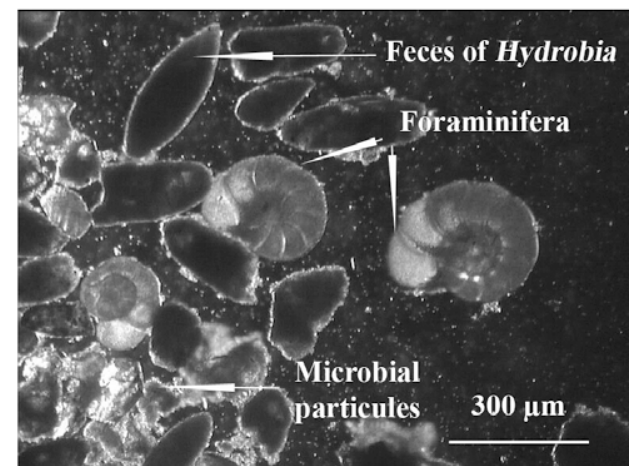

Figure 2. Sievied sediment from Brouage mudflat (A) before a treatment with Hydrobia ulvae $(\mathrm{B})$ after 2 days with Hydrobia ulvae $(\times 200)$.

(Table 2). The fact that the number of individuals, including juveniles, was not lower in the dishes with Hydrobia suggests that the gastropods did not ingest any foraminifera. This inference is corroborated by the absence of foraminifera in the guts of the 60 Hydrobia from the dishes.

The stomach contents of 50 gastropods collected from Brouage tidal flat contained in total only one small test (Ammonia) although foraminifera were abundant and available ( $\sim 1200$ living foraminifera in $50 \mathrm{~cm}^{3}: 89 \%$ Ammonia tepida, $8 \%$ Haynesina germanica, and $3 \%$ other species). We assume that this lone foraminifera was attached to the shell or snared in the aperture of a snail but was not actually part of the gut contents. These observations suggest that Hydrobia does not ingest foraminifera in the natural environment.

In a further test, six foraminifera were placed together with two $H$. ulvae and observed at the start and after 24 hours. The foraminifera maintained pseudopodial activity and appeared unharmed by the gastropods (Fig. 3), even though the gastropods had scraped them clean of the agglutinated cysts that incased the tests.

Several foraminifera extracted using this method were used for a bacterial grazing experiment. They fed normally on bacteria, showing that their health was not perceptibly affected by the cleaning process. They recovered, returned to their normal behaviors, and, when placed in sediment, they reconstruct their agglutinated cyst.

\section{DISCUSSION}

Several of methods for extraction and culture of foraminifera have been published (review in Anderson

TABLE 2. Abundance of foraminifera (tests $\mathrm{g}^{-1} \mathrm{dw}$; $\mathrm{dw}=$ dry weight) with standard deviation (SD) in the sediment before (T0) and after the 48-h treatment without and with Hydrobia ulvae.

\begin{tabular}{lrcc}
\hline \multicolumn{4}{c}{ Abundance $\left(\right.$ Tests $\left.^{-1} \mathrm{dw}\right) \pm \mathrm{SD}$} \\
\hline \multicolumn{1}{c}{ T0 } & Without H. ulvae & 20 H. ulvae \\
\hline $\begin{array}{l}\text { Ammonia tepida } \\
\text { Haynesina germa- } \\
\text { nica }\end{array}$ & $13 \pm 3$ & $12 \pm 2$ & $13 \pm 3$ \\
Sum & $16 \pm 4$ & $4 \pm 2$ & $4 \pm 2$ \\
\hline
\end{tabular}

and others, 1991) but all are highly time-consuming. In this study, we describe a new method for extracting quickly and inexpensively a large number of living benthic shelled foraminifera for culture in the laboratory. This method requires only two hours of actual work to extract 1000 tests (30 minutes for preparation of Petri dishes with sediment containing foraminifera and $H$. ulvae and $1 \mathrm{~h} 30 \mathrm{~min}$ for picking 1000 tests after the sediment treatment by $H$. ulvae). The rest of the work is carried out by $H$. ulvae. In comparison, the picking of 1000 tests from untreated sediment required 20 hours. The grazing activity of Hydrobia ulvae results in the formation of small cylindrical feces of compacted sediment and cleaning of agglutinated cysts from tests of living benthic foraminifera. Most of the

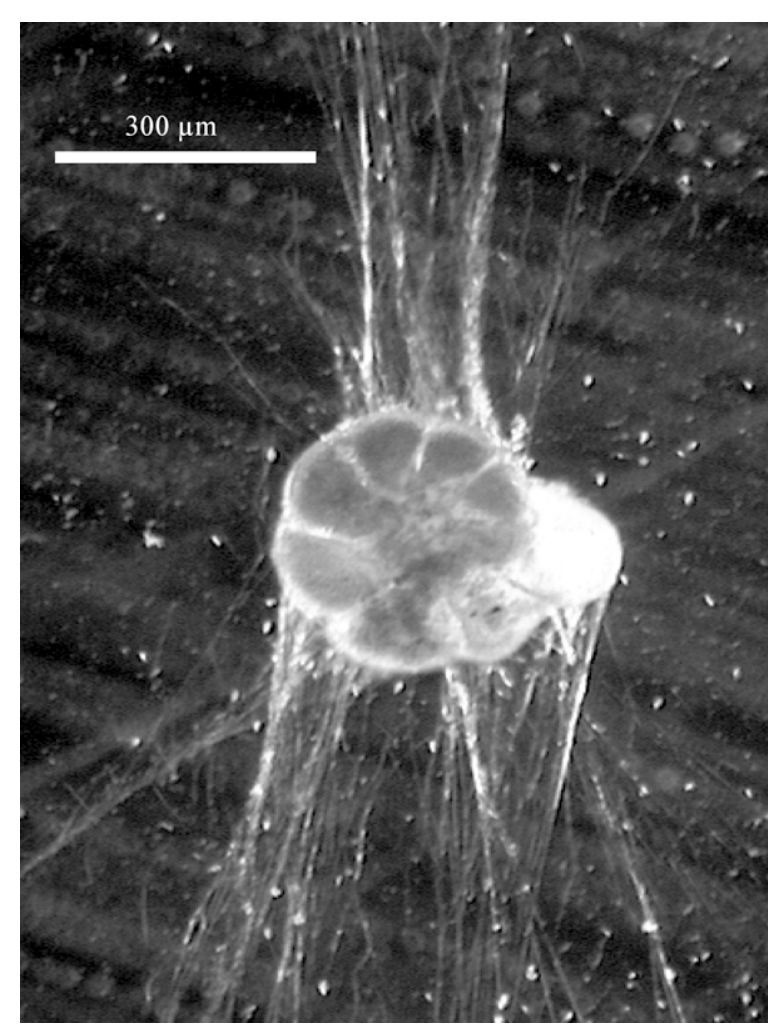

FIGURE 3. Pseudopodia emission of Ammonia tepida $(\times 200)$. 
organic and inorganic particles, even those in the cysts around foraminiferal tests, are grazed by the mud snails and digested or packed into feces. Small, isolated particles are no longer available to the foraminifera for construction of its cyst. The cleaning is harmless to the foraminifera since the gastropod does not have any feeding activity towards the foraminifera. This behavior is different from other gastropods, such as Olivella, that may selectively ingest living foraminifera, as reported by Hickman and Lipps (1983). However, Olivella is much bigger than Hydrobia ( $2 \mathrm{~cm}$ instead of $5 \mathrm{~mm}$ ). Moreover, unpublished studies have been carried out in the ile d'Yeu laboratory on Littorina littorea, Littorina saxatilis, Gibbula umbilicalis and Monodonta lineata, temperate gastropods much bigger than Hydrobia. These studies have shown that very few foraminifera are ingested accidentally by these gastropods when they feed on algae, but that there is no selective ingestion.

After testing the abundance of cleaned tests and the incubation times on a sediment sample of $1 \mathrm{~g}$, we concluded that the process is completed after two days with $40 \mathrm{H}$. ulvae. About the same number of tests was cleaned in the same amount of time by either 40 or $80 \mathrm{H}$. ulvae. The only benefit of using 80 snails rather than 40 was production of feces that were more compacted, which facilitated the picking of living foraminifera. After this treatment, recovery of living specimens with a fine brush was much easier and faster. Moreover, even smaller specimens were clearly discernable, which is not the case when they are hidden in cysts of sediment particles. For the same treatment time (two days), it is possible to increase the quantity of sediment treated by increasing the abundance of $H$. ulvae in bigger Petri dishes. The active feeding of $H$. ulvae in Petri dishes suggest that this method could be applied to muddy samples in which the mud snail does not occur, such as fine sediments from deeper subtidal habitats or those of the shelf or slope. We suggest too that this method might be adaptable in other coastal and brackish environments where $H$. ulvae does not live, by using other small deposit feeders, such as Hydrobia salsa and Hydrobia totteni in the U.S., Hydrobia knysnaensis in South Africa, and Hydrobia buccinoides in Australia. However, these applications require testing.

\section{ACKNOWLEDGMENTS}

This work was supported by the CNRS, contract PEVS and supported by the national research program Continental Ecosphere, Processes and Modeling (ECCO). We thank Jennifer Guarini for reviewing the English. We are grateful to C. A. Brunner and the Associated Editor of JFR for their help in improving the last version of the manuscript.

\section{REFERENCES}

Anderson, O. R., Lee, J. J., and FAber, W. W., JR., 1991, Collection, maintenance and culture methods for the study of living foraminifera, in Lee, J. J., and Anderson, O. R. (eds.), Biology of Foraminifera: Academic Press, p. 335-357.
ArNold, Z. M., 1954, Culture methods in the study of living Foraminifera: Paleontology, v. 28, p. 404-416.

, 1974, Field and laboratory techniques for the study of living foraminifera, in Hedley, R. H., and Adams, C. G. (eds.), Foraminifera: Academic Press, London, v. 1, p. 153-206.

Bender, H., and Hemleben, C. H., 1988, Calcitic cement secreted by agglutinated foraminifers grown in laboratory culture: Journal of Foraminiferal Research, v. 18, p. 12-45.

Bernhard, J. M., 2000, Distinguishing live from dead foraminifera: Methods review and proper applications: Micropaleontology, v. 46 , p. $38-46$.

Bijma, J., Faber, W. W., JR., and Hemleben, C., 1990, Temperature and salinity limits for growth and survival of some planktonic foraminifers in laboratory cultures: Journal of Foraminiferal Research, v. 20, p. 95-116.

Bowser, S. S., Alexander, S. P., Stockton, W. L., and Delaca, T. E., 1992, Extracellular matrix augments mechanical properties of pseudopodia in the carnivorous foraminiferan Astrammina rara: role in prey capture: Journal of Protozoology, v. 39, p. 724-732.

BRADSHAw, J. S., 1961, Laboratory experiments on the ecology of foraminifera: Contributions from the Cushman Foundation for Foraminiferal Research, v. 12, p. 87-106.

BuzAs, M. A., 1978, Foraminifera as prey for benthic deposit feeders: results of predator exclusion experiments: Journal of Marine Research, v. 36, p. 617-625.

CAREY, P. G., 1993, Long-term culture of marine benthic protists, in Kemp, P. F., Sherr, B. F., Sherr, E. B., and Cole, J. J. (eds.), Handbook of Methods in Aquatic Microbial Ecology: Lewis Publishers, Boca Raton, FL, USA, p. 213-227.

Haubois, A. G., Guarini, J. M., Richard, P., Hemon, A., Arotcharen, E., and Blanchard, G., 2004, Differences in spatial structures between juveniles and adults of the gasteropods Hydrobia ulvae on an intertidal mudflat (Marennes-Oléron Bay, France) potentially effect estimates of local demographic processes: Journal of Sea Research, v. 51, p. 63-68.

Hayward, P., Nelson smith, T., and Shields, C., 1996, Guide des bords de mer: Ed Delachaux et Niestlé, Genève, 351 p.

Heinz, P., Hemleben, C., and Kitazato, H., 2002, Time-response of cultured deep-sea benthic foraminifera to different algal diets: Deep-Sea Research, v. 49, p. 517-537.

Hickman, C. S., and LipPS, J. H., 1983, Foraminiferivory: Selective ingestion of Foraminifera and test alterations produced by the neogastropod Olivella: Journal of Foraminiferal Research, v. 13, p. $108-114$.

Jepps, M. W., 1942, Studies on Polystomella Lamarck (Foraminifera): Journal of Marine Biology Association U. K., v. 25, p. 612-665.

Khare, N., and NigAM, R., 2000, Laboratory experiment to record rate of movement of cultured benthic foraminifera: Oil and Natural Gas Corporation Bulletin, v. 37, p. 53-61.

Le CAlveZ, J., 1938, Recherche sur les foraminifères I: Développement et reproduction: Archives de Zoologie Expérimentale et Générale, v. 80 , p. $163-333$.

Linke, P., Altenbach, A. V., Graf, G., and Heeger, T., 1995, Response of deep-sea benthic foraminifera to a simulated sediment event: Journal of Foraminiferal Research, v. 25, p. 75-82.

Moodley, L., Boschker, H. T. S., Middelburg, J. J., Pel, R., Herman, P. M., De Deckere, E., and Heip, C. H. R., 2000, Ecological significance of benthic foraminifera: ${ }^{13} \mathrm{C}$ labelling experiments: Marine Ecology Progress Series, v. 202, p. 289-295.

Murray, J. W., and Bowser, S. S., 2000, Mortality, protoplasm decay rate, and reliability of staining techniques to recognize 'living' foraminifera: a review: Journal of Foraminiferal Research, v. 30 , p. $66-70$.

Myers, E. H., 1935, Culture methods for the marine foraminifera of the littoral zone: Transactions of the American Microscopical Society, v. 54, p. 264-267.

Stouff, V., DebenAy, J. P., and Lesourd, M., 1999, Origin of double and multiple tests in benthic foraminifera: Observations in laboratory cultures: Marine Micropaleontology, v. 36, p. 189-204. 